Gut, 1973, 14, 569-573

\title{
Determinants of serum antipyrine half-lives in patients with liver disease
}

\author{
R. A. BRANCH, CAROL M. HERBERT, AND ALAN E. READ \\ From the Department of Medicine, University of Bristol, Bristol Royal Infirmary
}

SUMMARY Antipyrine has been used as a model drug to investigate the effects of liver disease on drug metabolism in man. A prolongation in antipyrine half-life (T⿺ $\left.\frac{1}{2}\right)$ was found in patients with liver disease, patients with chronic liver disease showing a greater increase than those with acute, reversible pathology. The most marked prolongation in $\mathrm{T} \frac{1}{2}$ was found in association with hypoalbuminaemia and hypoprothrombinaemia, suggesting that the cause for these changes was defective protein synthesis of microsomal enzyme protein. This hypothesis was suppoited by demonstrating that enzyme-inducing agents, which are known to increase the amount of microsomal enzyme protein, reduced the antipyrine half-life.

As the liver is the major site for drug metabolism, patients with liver disease might be expected to show a defect in the elimination of drugs which are metabolized by the liver. In spite of traditional teaching to this effect (Sherlock, 1968; Fingl and Woodbury, 1970), most studies have failed to show a consistent relationship between liver disease and altered drug disposition. Salicylic acid, aminopyrine, dicoumerol, antipyrine (Brodie, Burns, and Weiner, 1959), tolbutamide (Nelson, 1964), and phenylbutazone (Weiner, Chenkin, and Burns, 1954)

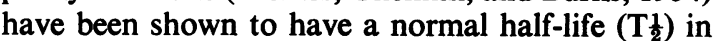
patients with liver disease, while some patients with liver disease have been shown to have a prolonged $\mathrm{T} \frac{1}{2}$ of carbenicillin (Hoffman, Cestero, and Bullock, 1970), chloramphenicol (Kunin, Glazko, and Finland, 1959), rifamycin (Acocella, Bonollo, Garimoldi, Mainardi, Tenconi, and Nicolis, 1972), and amylobarbitone (Mawer, Miller, and Turnberg, 1972). In a larger study, patients with liver disease who were receiving drugs known to induce drugmetabolizing enzymes (such as phenobarbitone) had a normal $T \frac{1}{2}$ of phenylbutazone while patients not receiving inducing agents had a prolonged $T \frac{1}{2}$ (Levi, Sherlock, and Walker, 1968).

In the majority of the previous studies the number of patients investigated was small and when a prolongation of the $T_{\frac{1}{2}}$ was demonstrated, the correlation with the underlying disease process was poor. In an attempt to predict which patients with

Received for publication 19 April 1973 liver disease would be likely to have abnormalities of drug metabolism, antipyrine was chosen as a model drug since it is completely absorbed when given orally, is almost entirely metabolized by the liver (Brodie and Axelrod, 1950), is not toxic, and has the additional advantage of not being protein bound so that changes in plasma proteins as a result of liver disease should not alter its disposition. The effect of liver disease on its $T^{\frac{1}{2}}$ has been measured and correlated with the clinical and biochemical parameters of hepatocellular function.

\section{Methods}

\section{SUBJECTS}

Fourteen normal drug-free subjects (aged 20-48) were studied as a control group. Eight subjects were studied on more than one occasion to assess day-today variation.

The 38 patients with liver disease were routine admissions to the Department of Medicine, Bristol Royal Infirmary. The patients were grouped according to their clinical diagnosis. In chronic liver disease the diagnoses of cirrhosis and chronic active hepatitis were confirmed in all cases by liver biopsy, laparotomy, or laparoscopy. In patients who had not previously undergone surgical portacaval anastomosis, the presence of oesophageal varices was assessed by barium swallow, and, in some instances, oesophagoscopy. Routine biochemical liver function tests were performed. If the prothrombin time was initially prolonged parenteral vitamin $\mathrm{K}$ was 
administered. A full drug history was taken, all drugs being maintained throughout the test period. Nitrazapam was the only hypnotic used.

\section{ANTIPYRINE TEST}

As there is no evidence in previous publications of dose-dependent kinetics for antipyrine, a standard dose of $1200 \mathrm{mg}$ antipyrine was administered orally after a fasting control blood sample was obtained. A further four or five blood samples $(10 \mathrm{ml})$ were taken between two and a half and 24 hours after the drug had been given. The serum was separated and frozen until assayed in duplicate by the method of Brodie, Axelrod, Soberman, and Levy (1949). From these data the $T_{\frac{1}{2}}$ was determined by regression analysis. When the fall in antipyrine concentration was less than $25 \%$ over 24 hours the $\mathrm{T}_{\frac{1}{2}}$ could not be calculated accurately from a 24-hour sampling period, so that the arbitrary upper limit of 50 hours was imposed.

Following the determination of the antipyrine $T_{\frac{1}{2}}$, 22 patients received phenobarbitone $30 \mathrm{mg}$ tds for three days and the $T \frac{1}{2}$ was determined again.

\section{Results}

In control subjects (fig 1) the $\mathrm{T} \frac{1}{2}$ of antipyrine was $12.0 \pm 1.7$ hours (SEM) (range 6-17 hours) which is consistent with previously published data (Brodie et al, 1959; Vesell and Page, 1969). In eight subjects who were retested four days later there was no significant difference between the two determinations, with a mean $\mathrm{T}_{2} \frac{1}{2}$ of $13.1 \pm 5.3$ hours (SD) for both determinations (intraclass correlation coefficient $r=-0.077$ ).

The 38 patients with liver disease (fig 1) showed a significant increase in the $T_{\frac{1}{2}}$ of antipyrine to $26.5 \pm 4.6$ hours. This mean is an underestimate because an arbitrary upper limit of 50 hours was assumed as values exceeding this were not assessed with accuracy. However, 13 patients had a $\mathrm{T} \frac{1}{2}$ within the normal range. When the underlying liver pathology was considered there was a more clearly defined separation between patients with chronic and acute liver disease. The $T \frac{1}{2}$ of antipyrine in 16

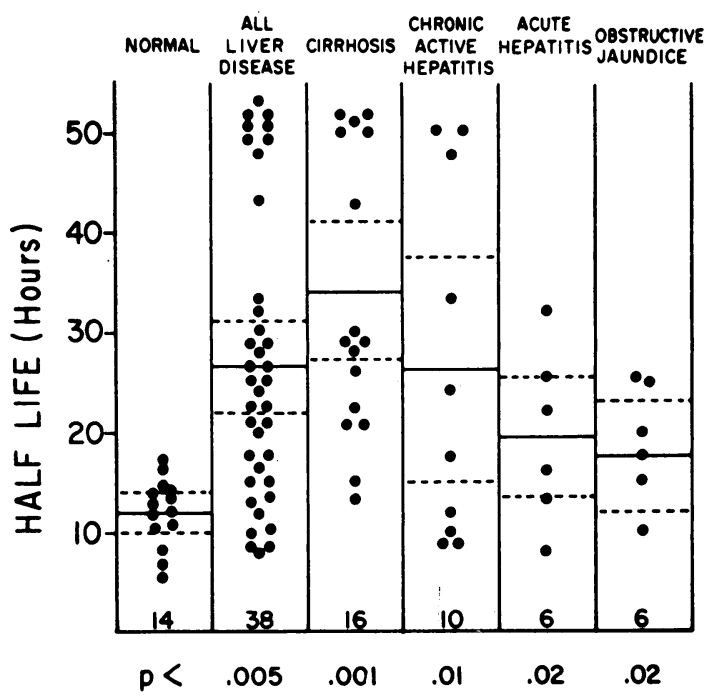

Fig 1 Comparison of the half-life of antipyrine with the clinical diagnosis (mean \pm 2 SEM).

patients with cirrhosis was markedly increased to $33.8 \pm 6.8$ hours, with only two patients in the normal range and the majority of the patients with cirrhosis had a greatly prolonged $T \frac{1}{2}$. Ten patients with chronic active hepatitis had a $\mathrm{T} \frac{1}{2}$ of antipyrine of $26 \cdot 2 \pm 11 \cdot 2$ hours and five of these who were not on corticosteroids had a $\mathrm{T}_{\frac{1}{2}}$ of $38.3 \pm 14 \cdot 6$.

In the small group of patients who had acute hepatitis and obstructive jaundice, the antipyrine $T_{\frac{1}{2}}$ was $19 \cdot 5 \pm 6.0$ hours and $17.8 \pm 5.4$ hours respectively. This increase was significant but in no instance was the $T \frac{1}{2}$ very prolonged.

In an attempt to correlate the effect of clinical complications occurring in patients with chronic liver disease with drug metabolism, the patients showing histological features of cirrhosis and not receiving enzyme-inducing agents have been considered in greater detailed (table I). There was no difference in antipyrine $T_{2}^{\frac{1}{2}}$ in the presence of portosystemic shunts, portosystemic encephalopathy, and fluid retention.

\begin{tabular}{|c|c|c|c|c|c|}
\hline & \multicolumn{4}{|c|}{ Antipyrine Half-life } & \multirow[t]{3}{*}{$\mathbf{P}$} \\
\hline & \multicolumn{2}{|c|}{ Clinical Feature Present } & \multicolumn{2}{|c|}{ Clinical Feature Absent } & \\
\hline & No. & Hours & No. & Hours & \\
\hline $\begin{array}{l}\text { Portosystemic anastomosis } \\
\text { Portosystemic encephalopathy } \\
\text { Fluid retention }\end{array}$ & $\begin{array}{r}11 \\
8 \\
10\end{array}$ & $\begin{array}{l}37 \cdot 0 \pm 9 \cdot 2 \\
41 \cdot 9 \pm 8 \cdot 0 \\
30 \cdot 4 \pm 11 \cdot 6\end{array}$ & $\begin{array}{r}9 \\
12 \\
10\end{array}$ & $\begin{array}{l}31 \cdot 0 \pm 9 \cdot 2 \\
31 \cdot 2 \pm 8 \cdot 4 \\
38 \cdot 2 \pm 8 \cdot 6\end{array}$ & $\begin{array}{l}\text { ns } \\
\text { ns } \\
\text { ns }\end{array}$ \\
\hline
\end{tabular}

Table I Comparison of clinical complications in chronic liver disease with the antipyrine half-life 


\begin{tabular}{|c|c|c|c|c|c|}
\hline & \multicolumn{2}{|c|}{ Antipyrine Half-life } & & & \multirow[t]{2}{*}{$\mathbf{P}$} \\
\hline & \multicolumn{2}{|c|}{ Subjects with a Normal Parameter } & \multicolumn{2}{|c|}{ Subjects with an Abnormal Parameter } & \\
\hline $\begin{array}{l}\text { Prothrombin index }(<80 \% \text { of control) } \\
\text { Serum albumin }(<3 \mathrm{~g} \%) \\
\text { Serum bilirubin }(<3 \mathrm{mg} \%) \\
\text { Serum alkaline phosphatase }(>30 \mathrm{King} \text { Armstrong }\end{array}$ & $\begin{array}{l}20 \\
15 \\
11\end{array}$ & $\begin{array}{l}24 \cdot 0 \pm 5 \cdot 0 \\
22 \cdot 0 \pm 5 \cdot 0 \\
26 \cdot 8 \pm 9 \cdot 0\end{array}$ & $\begin{array}{r}6 \\
11 \\
15\end{array}$ & $\begin{array}{l}47 \cdot 1 \pm 6 \cdot 0 \\
39 \cdot 3 \pm 7 \cdot 6 \\
31 \cdot 2 \pm 6 \cdot 8\end{array}$ & $\begin{array}{l}<0.001 \\
<0.001 \\
\text { ns }\end{array}$ \\
\hline $\begin{array}{l}\text { units) } \\
\text { Serum aspartate transaminase }(>50 \mathrm{IV} / \mathrm{I})\end{array}$ & $\begin{array}{l}8 \\
7\end{array}$ & $\begin{array}{l}27 \cdot 1 \pm 10 \cdot 0 \\
31 \cdot 7 \pm 10 \cdot 0\end{array}$ & $\begin{array}{l}18 \\
19\end{array}$ & $\begin{array}{l}30.4 \pm 6.4 \\
28.5 \pm 6.6\end{array}$ & $\begin{array}{l}\text { ns } \\
\text { ns }\end{array}$ \\
\hline
\end{tabular}

Table II Comparison of biochemical parameters with the antipyrine half-life in patients with liver disease not receiving enzyme-inducing agents

The biochemical parameters measured in all patients with liver disease, except patients receiving enzyme-inducing agents (table II), showed that patients with a serum albumin below $3 \mathrm{~g} \%$ or a prothrombin index below $80 \%$, in spite of parenteral vitamin $\mathrm{K}$, had a prolonged antipyrine $\mathrm{T} \frac{1}{2}$. The $\mathrm{T} \frac{1}{2}$ of patients who had either of these abnormalities was significantly longer than the $T \frac{1}{2}$ of the remaining patients with liver disease (fig 2). Abnormalities of serum bilirubin, alkaline phosphatase, and aspartate transaminase did not correlate with the prolongation in antipyrine $T \frac{1}{2}$.

The three-day course of phenobarbitone reduced the antipyrine $\mathrm{T} \frac{1}{2}$ from $30.3 \pm 6.2$ hours to $20.5 \pm$ 5.4 hours (paired $t$ test $P<0.001$ ). Prednisone was also found to shorten the $T_{\frac{1}{2}}$ in five patients with chronic active hepatitis to $13.8 \pm 6.0$ hours compared to that in untreated patients $(38.3 \pm 14 \cdot 6$ hours). This difference is unlikely to be due to clinical improvement following therapy as the clinical and biochemical parameters are similar in the two groups (table III) with one patient receiving prednisone dying in hepatic coma shortly afterwards.

\section{Discussion}

This study confirms the initial prediction that patients with liver disease would show an impairment in drug metabolism. The rate of antipyrine metabolism was reduced in all groups of liver disease. However, patients with the reversible pathology of acute hepatitis or obstructive jaundice showed less abnormality than patients with chronic cirrhotic liver disease.

Three possible explanations for the prolonged $T_{2}^{1}$ of antipyrine are altered drug distribution, altered liver blood flow, or a decreased rate of metabolism. Antipyrine is distributed in the total body water and this is known to increase in chronic liver disease in association with fluid retention. The volume of distribution could not be accurately calculated as the antipyrine was given orally. However, if complete

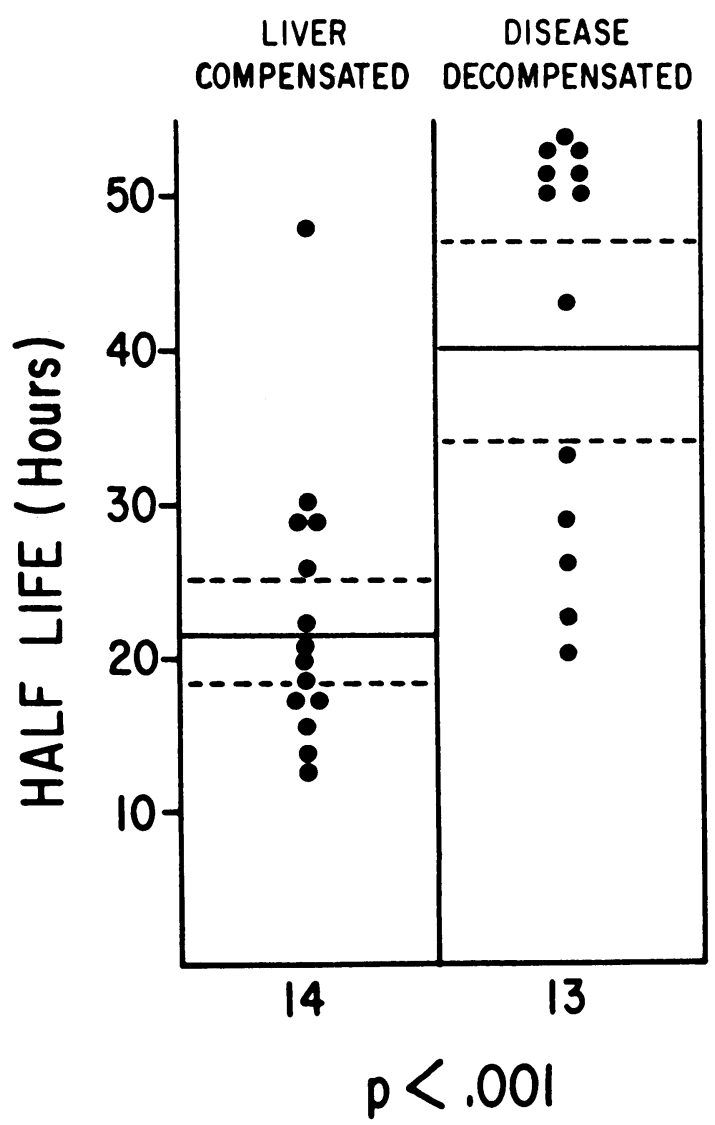

Fig 2 Comparison of the half-life of antipyrine with patients with liver disease not receiving enzyme-inducing agents. 'Compensated' serum albumin above $3 \mathrm{~g} \%$ and prothrombin index above $80 \%$. 'Decompensated' serum below $3 \mathrm{~g} \%$ or prothrombin index below $80 \%$.

rapid absorption is assumed there was no correlation of the $T_{2}^{\frac{1}{2}}$ with the apparent volume of distribution nor with the presence of gross fluid 


\begin{tabular}{|c|c|c|c|c|c|c|c|c|c|}
\hline & $\begin{array}{l}\text { Antipyrine } \\
T \frac{1}{2}(\text { Hours })\end{array}$ & $\begin{array}{l}\text { Porto- } \\
\text { systemic } \\
\text { Shunt } \\
\text { Present }\end{array}$ & $\begin{array}{l}\text { Porto- } \\
\text { systemic } \\
\text { Encepha- } \\
\text { lopathy }\end{array}$ & $\begin{array}{l}\text { Fluid } \\
\text { Retention }\end{array}$ & $\begin{array}{l}\text { Prothrombin } \\
\text { Index }(\%)\end{array}$ & $\begin{array}{l}\text { Albumin } \\
(\mathrm{g} \%)\end{array}$ & $\begin{array}{l}\text { Bilirubin } \\
(m g \%)\end{array}$ & $\begin{array}{l}\text { Alkaline } \\
\text { Phosphatase } \\
\text { (K.A. } \\
\text { units) }\end{array}$ & $\begin{array}{l}\text { Serum } \\
\text { Aspartate } \\
\text { Transaminase } \\
(I V)\end{array}$ \\
\hline \multirow{2}{*}{$\begin{array}{l}\text { Patient receiving } \\
\text { prednisone } \\
\text { Patients not receiving } \\
\text { prednisone }\end{array}$} & $13 \cdot 8 \pm 6 \cdot 0^{1}$ & 2 & 1 & 3 & $86 \cdot 0 \pm 6 \cdot 0$ & $3.4 \pm 0.27$ & $11 \cdot 2 \pm 7 \cdot 0$ & $48 \cdot 4 \pm 19 \cdot 1$ & $48.6 \pm \quad 3.8$ \\
\hline & $38 \cdot 3 \pm 14 \cdot 6^{1}$ & 1 & 0 & 1 & $78 \cdot 4 \pm 7 \cdot 3$ & $3.2 \pm 0.24$ & $9 \cdot 2 \pm 5 \cdot 8$ & $23 \cdot 2 \pm 7 \cdot 2$ & $190 \cdot 8 \pm 108$ \\
\hline
\end{tabular}

Table III Comparison of antipyrine half-life with clinical and biochemical parameters of 10 patients with chronic active hepatitis

${ }^{1} \mathbf{P}<0.001$

retention. The rate of elimination of some drugs is dependent upon liver blood flow (Whitsett, Dayton, and McNay, 1971; Stenson, Constantino, and Harrison, 1971) and a reduction in total liver blood flow might be expected to increase drug $\mathrm{T} \frac{1}{2}$. Disturbed regional blood supply in liver disease might therefore have been an explanation for our results. However, when the antipyrine $\mathrm{T}_{2} \frac{1}{2}$ in patients with evidence of portosystemic shunts was compared with that in patients with similar liver pathology, but no evidence of a shunt, there was no difference; both were increased from normal.

The evidence suggests that the impairment in antipyrine elimination is greatest when heptocellular function is severely compromised. A prolonged prothrombin time not responding to parenteral vitamin $\mathbf{K}$ and a low serum albumin are well established as features of failing function of the liver parenchyma, representing a failure of protein synthesis. Patients who had either of these abnormalities showed the greatest prolongation in $T_{\frac{1}{2}}$ and had no overlap with the normal range. Other clinical and biochemical parameters failed to correlate with the antipyrine $T \frac{1}{2}$; this is probably because they are not always directly related to the metabolic function of the liver and may be influenced by many other factors.

The previous report of normal $\mathrm{T} \frac{1}{2}$ of antipyrine in patients with liver disease (Brodie et al, 1959) might be explained by two factors. The first is that their study may not have included patients with hypoalbuminaemia or hypoprothrombinaemia. Secondly, these patients may have been receiving enzymeinducing agents, a factor which has been shown to obscure the prolongation of the $\mathrm{T}_{2} \frac{1}{2}$ of phenylbutazone in patients with liver disease (Levi et al, 1968). In the present series psychotropic, antihistaminic, and hypnotic drugs were actively avoided. Nitrazepam, previously shown not to cause enzyme induction (Bieger, de Jonge, and Loeliger, 1972), was the only hypnotic drug used. The only patients receiving a recognized enzyme-inducing agent were those with chronic active hepatitis receiving pred- nisone; although small, this group was representative in its composition of patients with hepatocellular failure yet the mean antipyrine $\mathrm{T}_{\frac{1}{2}}$ was within the normal range. A short three-day course of phenobarbitone in low doses was also found capable of reducing the half-life significantly. Indeed, the increased $T_{2} \frac{1}{2}$ of antipyrine might have returned to normal if patients with liver disease had been treated with an optimal course of enzyme-inducing agent.

The results of this study suggest that the cause of the prolongation of the $T_{\frac{1}{2}}$ of antipyrine in patients with liver disease might be defective synthesis of microsomal enzyme protein. First, the parameters of hepatocellular function associated with a marked prolongation of antipyrine $T \frac{1}{2}$ are related to impaired protein synthesis. Secondly, when phenobarbitone is given in small doses for a short time there was a reduction in half-life, and phenobarbitone is known to exert this effect through an increase in the absolute amount of microsomal enzyme (Conney, Davison, Gastel, and Burns, 1960). It is interesting that when prednisone is given for a longer period the antipyrine $T_{\frac{1}{2}}$ returned to normal, suggesting that impaired microsomal enzyme function can be significantly improved even in severe liver disease.

In conclusion, it is suggested that hepatic microsomal metabolism is generally impaired in liver disease. This impairment is greatest in patients with chronic disease and hypoprothrombinaemia or hypoalbuminaemia and can be reversed by the administration of enzyme inducing agents.

\footnotetext{
References

Acocella, G., Bonollo, L., Garimoldi, M., Mainardi, M., Tenconi, L. T., and Nicolis, F. B. (1972). Kinetics of rifampicin and isoniazid administered alone and in combination to normal subjects and patients with liver disease. Gut, 13, 47-53.

Bieger, R., de Jonge, H., and Loeliger, E. A. (1972). Influence of nitrazepam on oral anticoagulation with phenprocoumon. Clin. Pharmacol. Ther., 13, 361-365.

Brodie, B. B., and Axelrod, J. (1950). The fate of antipyrine in man. J. Pharmacol. exp. Ther., 98, 97-104.

Brodie, B. B., Axelrod, J., Soberman, R., and Levy, B. B. (1949) The estimation of antipyrine in biological materials. J. biol. Chem., 179, 25-29.
} 
Brodie,'B. B., Burns, J. J., and Weiner,'M. (1959). Metabolism of drugs in subjects with Laennec's cirrhosis. Med. exp. (Basel), 1, 290-292.

Conney, A. H., Davison, C., Gastel, R., and Burns, J. J. (1960). Adaptive increases in drug-metabolising enzyınes induced by phenobarbital and other drugs. J. Pharmacol. exp. Ther., 130, $1-8$.

Fingl, E., and Woodbury, D. M. (1970). Factors that modify drug effects and drug dosage. In The Pharmacological Basis of Therapeutics, edited by L. S. Goodman and A. Gilman, 4th ed., p. 23. Macmillan, London.

Hoffman, T. A., Cestero, R., and Bullock, W. E. (1970). Pharmacodynamics of carbenicillin in hepatic and renal failure. Ann. Intern. Med., 73, 173-178.

Kunin, C. M., Glazko, A. J., and Finland, M. (1959). Persistence of antibiotics in blood of patients with acute renal failure. II. Chloramphenicol and its metabolic products in the blood of patients with severe renal disease or hepatic cirrhosis. J. clin. Invest., 38, 1498-1508.

Levi, A. J., Sherlock, S., and Walker, D. (1968). Phenylbutazone and isoniazid metabolism in patients with liver disease in relation to previous drug therapy. Lancet, 1, 1275-1279.
Mawer, G. E., Miller, N. E., and Turnburg, L. A. (1972). Metabolism amylobarbitone in patients with chronic liver disease. Brit. $J$. Pharmacol., 44, 549-560.

Nelson, E. (1964). Rate of metabolism of tolbutamide in test subjects with liver disease or with impaired renal function. Amer. $J$. med. Sci., 248, 657-659.

Sherlock, S. (1968). Diseases of Liver and Biliary System, 4th ed. Blackwell, Oxford.

Stenson, R. E., Constantino, R. T., and Harrison, D. C. (1971). Interrelationships of hepatic blood flow, cardiac output, and blood levels of lidocaine in man. Circulation, 43, 205-211.

Vesell, E. S., and Page, J. G. (1969). Genetic control of phenobarbitalinduced shortening of plasma antipyrine half-lives in man. $J$. clin. Invest., 48, 2202-2209.

Weiner, M., Chenkin, T., and Burns, J. J. (1954). Observations on the metabolic transformation and effects of phenylbutazone in subjects with hepatic disease. Amer. J. med. Sci., 228, 36-39.

Whitsett, T. L., Dayton, P. G., and McNay, J. L. (1971). The effect of hepatic blood flow on the hepatic removal rate of oxyphenbutazone in the dog. J. Pharmacol. exp. Ther., 177, 246-255. 